\title{
Comparative Free Radical Scavenging Efficacy of Leaves Extract of Moringa Oleifera and Petals Extract of Hibiscus Sabdariffa
}

\author{
Garba Auwalu', Emeka John Dingwoke,,*, Adamude Fatima Amin², Nwobodo Ndubuisi Nwobodo,3, Mohammed \\ Mohammed Lawan ${ }^{1}$
}

\section{Garba Auwalu', Emeka John Dingwoke ${ }^{1, *}$, Adamude Fatima Amin ${ }^{2}$, Nwobodo Ndubuisi Nwobodo ${ }^{3,4}$, Mohammed Mohammed Lawan'}

'Department of Biochemistry, Faculty of Life Sciences, Ahmadu Bello University, Zaria, Kaduna, NIGERIA.

${ }^{2}$ Department of Biochemistry, Federal University Lafia, Nasarawa State, NIGERIA. ${ }^{3}$ Department of Pharmacology \& Therapeutics, College of Medicine, Enugu State University of Science \& Technology, Enugu, Enugu State, NIGERIA.

${ }^{4}$ Department of Pharmacology \& Therapeutics, College of Health Sciences, Nile University of Nigeria, FCT, Abuja, NIGERIA.

\section{Correspondence}

\section{Emeka John Dingwoke}

Department of Biochemistry, Faculty of Life Sciences, Ahmadu Bello University, Zaria, Kaduna, NIGERIA.

Phone no: +2347030665559;

E-mail: dinhimself@yahoo.com

History

- Submission Date: 11-07-2019;

- Review completed: 26-07-2019.

- Accepted Date: 14-08-2019

\section{DOI : 10.5530/pj.2019.11.207}

Article Available online http://www.phcogj.com/v11/i6

\section{Copyright}

(C) 2019 Phcogj.Com. This is an openaccess article distributed under the terms of the Creative Commons Attribution 4.0 International license.

\begin{abstract}
Background: Use of molecules with antioxidant properties have evolved as effective strategy for preventing oxidative damage caused by reactive oxygen species. Moringa oleifera and Hibiscus sabdariffa are ancient plants with antioxidant properties, and have served numerous therapeutic purposes, in addition to their nutritional benefits. Aim: This in vitro study compared the free radical scavenging efficacy of ethylacetate leaves extract of Moringa oleifera and ethylacetate petal extract of Hibiscus sabdariffa. Method: Determinations were carried out following standard procedures for analytical experiments. The leaves of Moringa oleifera and petals of Hibiscus sabdariffa were extracted by cool maceration with distilled water and ethylacetate, independently for 48 hours using soxhlet extractor. The free radical scavenging activities of the extracts were determined spectrophotometrically. DPPH free radical was used to determine the free radical scavenging activities of the extracts. The reducing power efficacy of the extracts was determined by their ability to reduce $\mathrm{Fe}^{3+}$ to $\mathrm{Fe}^{2+}$ ions using FERAP. Results: Ethylacetate extract of Hibiscus sabdariffa petals had higher free radical scavenging efficacy and more reducing power with an inhibitory concentration $\left({ } \mathrm{C}_{50}\right)$ of $1.57 \mathrm{mg} / \mathrm{ml} \mathrm{compared} \mathrm{to} \mathrm{the}$ ethylacetate extract of Moringa oleifera leaves which had an $I_{50}$ of $2.60 \mathrm{mg} / \mathrm{ml}$. Phytochemical profile revealed that the predominant compounds in both extracts were flavonoids, phenols, and amino acids. Conclusion: This study has established that ethylacetate extract of the Petals of Hibiscus sabdariffa has more reducing power and free radical scavenging efficacy compared to ethylacetate extract of Moringa oleifera leaves. These plant parts could serve as novel sources for clinically efficient antioxidants.
\end{abstract}

Key words: Oxygen-free radicals, Oxidative stress, Antioxidant, Free radical scavenger, Moringa oleifera, Hibiscus sabdariffa.

\section{INTRODUCTION}

Antioxidants are agents or compounds that are capable of inhibiting the oxidation processes that occur under the influence of reactive nitrogen species (RNS) and reactive oxygen species (ROS) such as singlet oxygen $(\mathrm{O}$.$) , hydroxyl (. \mathrm{OH})$, peroxide $\left(\mathrm{H}_{2} \mathrm{O}_{2}\right)$ and superoxide $\left(\mathrm{O}_{2}\right.$.) radicals. Antioxidants play crucial role in the defense mechanism of living cells against the pathologies associated with the attack of ROS and RNS. ${ }^{1-3}$ Antioxidants mediate their role of preventing oxidant-induced cell damages either through the reduction of ROS generation, scavenging ROS, or interfering with ROS-induced alterations. ${ }^{1}$ By its role of reducing the oxidative damages in the body and inhibiting lipid peroxidation, antioxidants retard the progress of many diseases. ${ }^{1,3,4}$ An imbalance between ROS and antioxidants defense system results to abnormal physiological condition known as oxidative stress ${ }^{1,3}$. During energy production in the body by oxidation process, the associated oxygen molecule has the tendency to generate free radicals ${ }^{5}$. These free radicals which are by-products of the oxidation attacks specific region in the body, leading to oxidative stress, and ultimately results to the damage of affected tissues and organs. Under stress, the living cell end up having more reactive oxygen species than antioxidant, this imbalance leads to deleterious damage of the cellular components, particularly lipid peroxidation, protein oxidation and deoxyribonucleic acid mutation. ${ }^{3}$ This is considered to be the major reason for many diseases such as cancer, cardiovascular diseases, neurodegenerative diseases, rheumatoid arthritis, atherosclerosis, hypertension among others. ${ }^{1,2}$ Even though almost all organisms possess antioxidants and several enzyme systems such superoxide dismutase, catalase, glutathione peroxidase and glutathione reductase to protect them from oxidative damage, these systems are inadequate to prevent the damage entirely, hence, the need to supplement antioxidants for efficient and adequate scavenging of free radical. ${ }^{2}$ Currently available synthetic antioxidants including Butylated hydroxytoluene (BHT), Butylated hydroxyanisole (BHA), Gallic acid among others have been found to cause negative health effects, ${ }^{6,7}$ hence, the search for antioxidants without side effects, from natural sources, with keen interest in plants due to the bioactive secondary metabolites they produce. ${ }^{8,9}$ It has been established that anti-oxidants play important role in the prevention of many chronic diseases including cancer, cardiovascular disease, atherosclerosis, diabetes mellitus, asthma, hepatitis and arthritis. ${ }^{10,11}$ The consumption of traditional diets prepared with spices, medicinal and aromatic 
herbs have attracted increasing interest among consumers and scientists because they exhibit antioxidant activity, attributed to a variety of bioactive phytochemicals present. ${ }^{12,13}$ Antioxidants are thus useful in protecting cells from oxidative damage. ${ }^{14}$ Studies have reported that polyphenols, such as flavonoids, hydroxycinnamic acids and proanthocyanidins, act as powerful antioxidants. ${ }^{15,16}$ Phenolic antioxidants have been recognized as an important class of food ingredients and are being added to various food products in order to provide additional health benefits. ${ }^{17,18}$ Studies have reported that natural antioxidant molecules found in the bark of certain trees can inhibit reactive oxygen species and thus contribute to the health benefits of the forest biomass. ${ }^{19-21}$ Based on the fore-going, it has been established that plant-based system plays essential role as a source of novel and effective therapeutic agents, especially in Africa. Antioxidants from natural sources are preferred and advantageous since there is no report of toxicity or side effects associated with increased intake. More so, they are better alternative in view of the variety of their structures and chemical interactions with cells during their protective biological activities. Moringa oleifera is one of the medicinal plants known to possess antioxidant activities. It is considered as one of the world's most useful trees, since almost every part of the plant have been used for treatments of various ailments including ascites and rheumatism, as well as cardiac and circulatory stimulants. This is attributed to the presence of alkaloids, carotenoids, tannins, anthraquinones among other secondary metabolites. ${ }^{22,23}$ Nutritionally, the leaves contain essential amino acids, vitamins, minerals and $\beta$-carotene, making it an invaluable commodity in the food industries. ${ }^{14,21}$ Similarly, Hibiscus sabdariffa; the plant from which the Nigeria's popular local juice drink known as Zobo is made is another plant that is well known for its medicinal properties. It is rich in vitamins, natural carbohydrate, protein, tannins, gums and other antioxidants including minerals. Hibiscus sabdariffa has been used and are still being used to prevent oxidation by free radicals. ${ }^{24}$ Different reports have been documented about nutritional and health benefits of Moringa oleifera and Hibiscus sabdariffa but there is no report on the comparative analysis of the reducing power and free radical scavenging activity of ethylacetate leaves extract of Moringa oleifera and ethylacetate petal extract of Hibiscus subdariffa, hence the first report that compared their free radical scavenging activity using 2,2-diphenyl-1 picrylhydrazyl (DPPH) free radical and ferric ion reducing antioxidant power (FRAP).

\section{MATERIALS AND METHOD}

\section{Chemicals and reagents}

Ethylacetate, 1-1-diphenyl-2-picrylhydrazyl (DPPH), methanol, hydrochloric acid, potassium ferricyanide, trichloroacetic acid, phosphate buffer, Mayers reagent, ferric chloride, $\mathrm{NaOH}, 0.2 \%$ Ninhydrin reagent, dimethylsulfoxide (DMSO), Ferric ion reducing antioxidant power (FRAP) were purchased from sigma Aldrich USA. All other chemicals were of analytical grade.

\section{Plant materials and preparation of extracts}

Leaves of Moringa oleifera and Petals of Hibiscus sabdariffa were collected in February 2015 from their natural habitat in Sabon-Gari Local Government Area, Kaduna State, Nigeria. They were identified and authenticated at the Herbarium by Taxonomist in the department of Botany, Ahmadu Bello University Zaria with voucher number 3317 and 1056 respectively. They were washed with clean tap water and dried at room temperature for 14 days at $38{ }^{\circ} \mathrm{C}$. The dried samples were pulverized using pestle and mortar, sieved and stored in air-tight container until used. Using a weighing balance (Contech" instruments Ltd India. Model CAC-224), $25 \mathrm{~g}$ of each of the powdered plant parts were weighed and extracted by cool maceration with $250 \mathrm{ml}$ distilled water and ethylacetate, independently for 48 hours using soxhlet extractor. About 3 drops of chloroform was added to ensure there was no fungi growth during the extraction duration of 48 hours. The extracts were filtered using Whatman filter paper No.1 and concentrated by freeze drying using bench top freeze dryer $\left(\right.$ Labconco $\left.^{\mathrm{TM}}\right)$ at $4{ }^{\circ} \mathrm{C}$ for about 3 hours. They were stored in the refrigerator until used. This served as the crude extract. ${ }^{25,26}$

\section{Determination of extract yield (\%)}

The percentage yield of each extract was obtained by dividing the weight of the concentrated crude extract by the initial weight $(25 \mathrm{~g})$ of dry milled starting material and multiplying the ratio by 100 , thus:

\section{$\frac{\text { Mass yield of extract }}{\text { Mass of plant material }} \times \frac{100}{1}$}

Preliminary phytochemical analysis was carried out for the extract as per standard methods described. ${ }^{27}$

\section{DPPH free radical scavenging activity}

The 2, 2-Diphenyl-1-Picrylhydrazyl (DPPH) assay was carried out following the method described by Torres-Castillo et al. ${ }^{28}$ Briefly, 2.9 $\mathrm{mL}$ of $60 \mu \mathrm{M}$ DPPH' radical were added to $100 \mu \mathrm{L}$ of each extract at different concentrations thus: $(1 \mathrm{mg} / \mathrm{ml}, 0.75 \mathrm{mg} / \mathrm{ml}, 0.5 \mathrm{mg} / \mathrm{ml}$ and $0.25 \mathrm{mg} / \mathrm{ml}$ ). Then, samples were kept in a dark place, and after 30 minutes the absorbance was measured at $517 \mathrm{~nm}$. Lower absorbance of the reaction mixture indicates higher DPPH free radical scavenging activity. The control sample was a mixture of $100 \mu \mathrm{L}$ of DPPH and distilled water. The free radical scavenging activity of the extracts was calculated with the following equation and expressed as DPPH percent of inhibition:

$$
\operatorname{Inhibition}(\%)=\frac{\left(A_{\text {blank }}-A_{\text {sample }}\right)}{\left(A_{\text {blank }} X 100\right)}
$$

Where ${ }^{A}$ blank is the absorbance of the control reaction (mixture of all the reagents except the extract), ${ }^{A}$ sample is the absorbance of the sample mixture. The $\mathrm{IC}_{50}$ is the concentration giving $50 \%$ inhibition of $\mathrm{DPPH}$. It was determined by a graph of percentage inhibition (I \%) versus extract concentration.

\section{Reducing power assay}

Antioxidant activity of the leaves extract of Moringa oleifera and the Petal extract of hibiscus sabdariffa in different extracting solvents (distilled water and ethyl acetate) were determined to assess their ferric ion $\left(\mathrm{Fe}^{3+}\right)$ reducing ability. ${ }^{29}$ This method is based on the ability of the extracts to reduce $\mathrm{Fe}^{3+}$ to $\mathrm{Fe}^{2+}$ ions. Different concentrations $(1 \mathrm{mg} / \mathrm{ml}$, $0.75 \mathrm{mg} / \mathrm{ml}, 0.5 \mathrm{mg} / \mathrm{ml}$ and $0.25 \mathrm{mg} / \mathrm{ml}$ ) of each extract were prepared and $1 \mathrm{~mL}$ of each concentration was mixed with $2.5 \mathrm{~mL}$ of phosphate buffer $(0.2 \mathrm{M}, \mathrm{pH} 6.8)$ and $2.5 \mathrm{~mL}$ of $1 \%$ potassium ferricyanide. The mixture was incubated in a water bath at $50^{\circ} \mathrm{C}$ for 20 minutes. To this mixture, $2.5 \mathrm{~mL}$ of $10 \%$ trichloroacetic acid was added and then centrifuged at $3000 \mathrm{x}$ g for 10 minutes. The upper layer of the solution $(2.5 \mathrm{~mL})$ was mixed with $2.5 \mathrm{~mL}$ of distilled water and $0.5 \mathrm{~mL}$ of $0.1 \%$ ferric chloride was added. Absorbance of the Pert Prussian blue solution formed was measured at $700 \mathrm{~nm}$. Ascorbic acid was used as standard reference compounds for comparison and prepared in same concentrations as the extracts.

\section{RESULT}

The free radical scavenging activity using DPPH is shown in Table 3. At $0.25 \mathrm{mg} / \mathrm{ml}$, there was no significant difference between the ethylacetate extract of Moringa oleifera and aqueous extract of Moringa oleifera and Hibiscus sabdariffa. There was no significant difference between the aqueous and ethylacetate extracts of Hibiscus sabdariffa. 
This implies that similar level of scavenging activity was exhibited by the extracts. This similarity in activity could be attributed to the presence of same bioactive compounds. However, the scavenging activity of the ethylacetate extract of the two plant parts differs significantly, indicating variation in the composition of the bioactive compounds. At 0.5 and $0.75 \mathrm{mg} / \mathrm{ml}$, no significant difference were observed among the various extracts but at $1.0 \mathrm{mg} / \mathrm{ml}$, the ethylacetate extract of Hibiscus sabdariffa exhibited a high level of scavenging activity with a value of $32.26 \pm 1.04$, compared to the aqueous extract of Moringa oleifera with a value of $13.31 \pm 5.33$. In the determinations, the standard (ascorbic acid) depicted the highest level of scavenging activity. There was significant difference in the reducing power potential of Moringa oleifera and Hibiscus sabdariffa at different concentrations using Ferric ion Reducing Antioxidant Power (FRAP) as shown in Table 4. At 0.25 $\mathrm{mg} / \mathrm{ml}$, there was significant difference between the ethylacetate extract of Hibiscus sabdariffa and the aqueous extract of Moringa oleifera, with the former possessing more reducing power. Interestingly, similar trends were observed for the two plant parts at increasing extract concentration from 0.50 to $1.0 \mathrm{mg} / \mathrm{ml}$. The phytochemical profile as shown in Table 1 revealed that amino acids, phenols, and flavonoids were present in both the aqueous and ethylacetate extracts of the leaves of Moringa oleifera and petals of Hibiscus sabdariffa. Alkaloid was present in the aqueous and ethylacetate extracts of Moringa oleifera but were absent in the aqueous and ethylacetate extracts of Hibiscus sabdariffa. Interestingly, tannins were present in the aqueous and ethylacetate extracts of Hibiscus sabdariffa but absent in the aqueous and ethylacetate extracts of Moringa oleifera. Saponins were present only in the aqueous extract of Moringa oleifera. From the results of the successive extraction (Table 2), Moringa oleifera gave the highest yield of $5.9 \%$ with distilled water and low yield of $3.63 \%$ with ethylacetate, while the ethylacetate extract of Hibiscus sabdariffa gave the highest yield of $14.75 \%$ and a corresponding low yield of $4.55 \%$ with distilled water.

Table 1: Phytochemical profile of the extracts.

\begin{tabular}{ccccc}
\hline $\begin{array}{c}\text { Phytochemical } \\
\text { constituents }\end{array}$ & \multicolumn{2}{c}{ Moringa oleifera } & \multicolumn{2}{c}{ Hibiscus sabdariffa } \\
\hline & aqueous extract & ethylacetate extract & aqueous extract & ethylacetate extract \\
\hline Alkanoid & + & + & - & - \\
Flavonoid & + & + & + & + \\
Phenols & + & + & + & + \\
Saponin & + & - & - & - \\
Tannin & - & - & + & + \\
Amino acids & + & + & + & + \\
\hline
\end{tabular}

(+) present, (-) not present.

Table 2: The yield of successive extraction of the plant parts.

\begin{tabular}{ccccc}
\hline Sample & \multicolumn{2}{c}{ Moringa oleifera } & \multicolumn{2}{c}{ Hibiscus sabdariffa } \\
\hline Solvent used in extraction & Distilled water & ethylacetate & Distilled water & Ethylacetate \\
\hline \% yield & 5.9 & 3.63 & 4.55 & 14.75 \\
\hline
\end{tabular}

Table 3. DPPH scavenging activity by extracts of Moringa oleifera and $\boldsymbol{H}$.sabdariffa.

\begin{tabular}{cccccc}
\hline & \multicolumn{5}{c}{ Percentage inhibition (\%l) } \\
\cline { 2 - 6 } Extract Conc. $(\mathrm{mg} / \mathrm{ml})$ & \multicolumn{2}{c}{ Moringa oleifera } & \multicolumn{2}{c}{ Hibiscus sabdariffa } & Standard \\
\cline { 2 - 6 } & $\begin{array}{c}\text { aqueous } \\
\text { extract }\end{array}$ & $\begin{array}{c}\text { ethylacetate } \\
\text { extract }\end{array}$ & $\begin{array}{c}\text { aqueous } \\
\text { extract }\end{array}$ & $\begin{array}{c}\text { ethylacetate } \\
\text { extract }\end{array}$ & ascorbic acid \\
\hline 0.25 & $6.91 \pm 4.24^{\mathrm{ab}}$ & $5.56 \pm 3.15^{\mathrm{a}}$ & $13.22 \pm 5.03^{\mathrm{abc}}$ & $12.83 \pm 0.89^{\mathrm{c}}$ & $47.47 \pm 4.50^{\mathrm{d}}$ \\
0.50 & $7.50 \pm 6.09^{\mathrm{a}}$ & $12.59 \pm 1.77^{\mathrm{ab}}$ & $13.98 \pm 2.25^{\mathrm{abc}}$ & $19.07 \pm 7.76^{\mathrm{abc}}$ & $50.67 \pm 1.46^{\mathrm{d}}$ \\
0.75 & $8.31 \pm 3.77^{\mathrm{a}}$ & $16.12 \pm 2.04^{\mathrm{b}}$ & $17.39 \pm 12.74^{\mathrm{bc}}$ & $30.64 \pm 0.36^{\mathrm{c}}$ & $52.79 \pm 1.37^{\mathrm{d}}$ \\
1.00 & $13.31 \pm 5.33^{\mathrm{a}}$ & $19.75 \pm 3.06^{\mathrm{ab}}$ & $33.00 \pm 13.90^{\mathrm{bc}}$ & $32.26 \pm 1.04^{\mathrm{c}}$ & $55.14 \pm 2.08^{\mathrm{d}}$ \\
\hline
\end{tabular}

Means with different superscript along the same horizontal array differ significantly $(p<0.05)$ from each other. IC value $_{50}$ for ascorbic acid, Hibiscus sabdariffa ethylacetate extract, Hibiscus sabdariffa aqueous extract, Moringa oleifera ethylacetate extract and Moringa oleifera aqueous extract were $0.47 \mathrm{mg} / \mathrm{ml}, 1.57 \mathrm{mg} / \mathrm{ml}, 1.84 \mathrm{mg} / \mathrm{ml}, 2.60 \mathrm{mg} / \mathrm{ml} \mathrm{and} 5.80 \mathrm{mg} / \mathrm{ml}$ respectively.

Table 4: Ferric ion reducing antioxidant power (FRAP) of Moringa oleifera and Hibiscus sabdariffa.

\begin{tabular}{cccccc}
\hline \multirow{2}{*}{$\begin{array}{c}\text { Extract } \\
\text { Conc. }(\mathrm{mg} / \mathrm{ml})\end{array}$} & \multicolumn{4}{c}{ Absorbance $(700 \mathrm{~nm})$} \\
\cline { 2 - 6 } & Moringa oleifera & \multicolumn{3}{c}{ Hibiscus sabdariffa } & Standard \\
\cline { 2 - 6 } & aqueous extract & ethylacetate extract & aqueous extract & ethylacetate extract & ascorbic acid \\
\hline 0.25 & $0.65 \pm 0.04^{\text {cd }}$ & $0.62 \pm 0.04^{\mathrm{c}}$ & $0.53 \pm 0.03^{\mathrm{ab}}$ & $0.52 \pm 0.02^{\mathrm{a}}$ & $1.39 \pm 0.05^{\mathrm{e}}$ \\
0.50 & $0.74 \pm 0.08^{\mathrm{cd}}$ & $0.71 \pm 0.01^{\mathrm{c}}$ & $0.64 \pm 0.01^{\mathrm{ab}}$ & $0.61 \pm 0.03^{\mathrm{a}}$ & $1.45 \pm 0.04^{\mathrm{e}}$ \\
0.75 & $0.77 \pm 0.02^{\mathrm{cd}}$ & $0.76 \pm 0.01^{\mathrm{c}}$ & $0.71 \pm 0.02^{\mathrm{ab}}$ & $0.66 \pm 0.06^{\mathrm{a}}$ & $1.66 \pm 0.03^{\mathrm{e}}$ \\
1.00 & $0.99 \pm 0.14^{\mathrm{cd}}$ & $0.81 \pm 0.01^{\mathrm{b}}$ & $0.87 \pm 0.07^{\mathrm{bc}}$ & $0.70 \pm 0.03^{\mathrm{a}}$ & $1.75 \pm 0.01^{\mathrm{e}}$ \\
\hline
\end{tabular}

Means with different superscript along the same horizontal array differ significantly $(p<0.05)$ from each other. 


\section{DISCUSSION}

Medicinal plants are regularly screened for free radical scavenging properties basically from the reports on their safety, efficacy and cost effectiveness. ${ }^{30}$ We investigated comparative free radical scavenging efficacy of ethylacetate leaves extract of Moringa oleifera and ethylacetate petal extract of Hibiscus sabdariffa. Interestingly, we have established that the free radical scavenging agents present in the petals of Hibiscus sabdariffa is best extracted using ethylacetate. This is probably due to the intermittently polar nature of ethylacetate (polarity index of 4.4), thus having the ability of extracting series of saturated and unsaturated fatty acids and other bioactive agents with free radical scavenging potentials, while water is the solvent of choice for the extraction of the scavengers from the leaves of Moringa oleifera.

Result of the phytochemical constituents (Table 1) revealed that flavonoid, amino acid and phenol were present in all the extracts; in addition, tannin was present in both the ethylacetate and aqueous extracts of Hibiscus sabdariffa. The synergy of the bioactive compounds could be the most probable reason for the higher free radical scavenging effect observed with the ethylacetate extract of Petals of the plant. This is in tandem with previous report that phenols contributed more to the antioxidant activity of Hibiscus sabdariffa calyx compared to flavonoids. ${ }^{31,32}$ Similarly, the presence of saponin in addition to the flavonoid, amino acid, phenol and alkanoid in the aqueous extract of Moringa oleifera is a possible reason for the free radical scavenging effects observed with the aqueous extract, unlike the ethylacetate extract that exhibited low scavenging effect. This implies that the viability and potency of free radical scavengers extracted is a function the type of the solvents used for extraction, similar observation were recorded previously. ${ }^{33,32}$ A synthetic free radical 2,2-diphenyl1picrylhydrazyl (DPPH) was used to measure the in vitro ability of the extracts to scavenge free radicals. The effects of phenolic compounds on scavenging DPPH radical are thought to be due to their hydrogen donating ability to the unstable DPPH free radical that accepts an electron or hydrogen to become a stable diamagnetic molecule..$^{30}$ It is most likely that the decrease in absorbance of DPPH radical caused by the phenolic compound in our result is due to reduction reaction between antioxidant molecules in the extracts and the radicals. Although the amount of DPPH scavenged by the two plant extracts in the respective extracting solvents are not equivalent to the standard; ascorbic acid. However, this efficacy is adequate to infer that the extracts; especially ethylacetate extract of Hibiscus sabdariffa exacts viable potential in scavenging free radicals.

The result obtained from the inhibition studies on the DPPH, ascorbic acid (standard) had lower inhibitory concentration $\left(\mathrm{IC}_{50}\right)$ of $0.47 \mathrm{mg} /$ $\mathrm{ml}$, compared to the $1.84 \mathrm{mg} / \mathrm{ml}$ of Hibiscus sabdariffa aqueous extract and $1.10 \mathrm{mg} / \mathrm{ml}$ of Hibiscus sabdariffa ethylacetate extract, which in turn is lower than the corresponding $5.8 \mathrm{mg} / \mathrm{ml}$ of Moringa oleifera aqueous extract and $2.6 \mathrm{mg} / \mathrm{ml}$ of Moringa oleifera ethylacetate extract, indicating that the free radical scavengers were more concentrated in the ethylacetate extract of Hibiscus sabdariffa than any other extracts. This further justifies our claim that free radical scavengers are present in the Petals of Hibiscus sabdariffa extracted with ethylacetate. The observed low $\mathrm{IC}_{50}$ value indicated high potentials to scavenge $50 \%$ of the free radicals. This finding is in agreement with the report that free radical scavengers are present in the leaves of Moringa oleifera and Azadiracta indica. ${ }^{28-30}$

The reducing power of the free radical scavengers in the extracts was confirmed by the ability of the scavengers in the extracts to donate electron(s), causing the reduction of ferric ions $\left(\mathrm{Fe}^{3+}\right)$ to ferrous ions $\left(\mathrm{Fe}^{2+}\right){ }^{34}$ Different concentrations of the sample extracts were charged with solutions containing $\mathrm{Fe}^{3+}$ and the absorbance were measured at $700 \mathrm{~nm}$. The absorbance gave indication about the concentration of $\mathrm{Fe}^{2+}$ in solution, so the higher this absorbance, the higher the concentration of $\mathrm{Fe}^{2+}$ and the higher the ability of the extract of interest to donate electrons. This implies that the higher the reducing power of the extract, the greater the antioxidant activity. ${ }^{35}$

From Table 3, Moringa oleifera aqueous extract at $1.0 \mathrm{mg} / \mathrm{ml}$ had high ability to donate electron due to high absorbance recorded and Hibiscus sabdariffa ethylacetate extract had lowest ability to donate electrons in order to facilitate the reduction of ferric ions to ferrous ions because of its low absorbance. Moringa oleifera extracts had higher reducing power than did the Hibiscus sabdariffa. The result was in agreement with previous report. ${ }^{34}$ Having explored the free radical scavenging profile of the leaves of Moringa oleifera and Petals of Hibiscus sabdariffa, the bioactive compounds present in the extracts of these plants are promising sources of free radical scavengers.

\section{CONCLUSION}

In conclusion, the petals of Hibiscus sabdariffa extracted with ethylacetate had more free radical scavenging potentials compared to the ethylacetate leaves of Moringa oleifera. This became evident by the Ferric ion Reducing Antioxidant Power (FRAP) of the ethylacetate extract of Hibiscus sabdariffa which reduced $\mathrm{Fe}^{3+}$ to $\mathrm{Fe}^{2+}$. However, irrespective of their free radical scavenging and FRAP abilities, the synergy of the two plant parts can be useful in the field of drug discovery and are better alternatives to the life-threatening synthetic sources.

\section{ACKNOWLEDGEMENT}

The authors are thankful to the Department of Biochemistry, Ahmadu Bello University Zaria for giving us bench space for this work.

\section{References}

1. Turan B. Role of antioxidants in redox regulation of diabetic cardiovascula complications. Curr Pharm Biotechnol. 2010;11(8):819-36.

2. Rochette $L$, Zeller M, Cottin $Y$, Vergely $C$. Diabetes, oxidative stress and therapeutic strategies. Biochim Biophys Acta. 2014;1840(9):2709-29.

3. Valko M, Rhodes CJ, Moncol J, Izakovic M, Mazur M. Free radicals, metals and antioxidants in oxidative stress-induced cancer. Chem Biol Interact. 2006;160(1):1-40.

4. Percival M. Antioxidants clinical nutrition insights. 1998

5. Koksal E. Antioxidant activity of cauliflower (Brassica oleracea L.). Turk J Agric. 2008;32:65-78

6. Stevanovic T, Diouf N, Garcia-Perez ME. Bioactive polyphenols from healthy diets and forest biomass. Curr Nutri Food Sci. 2009;5(4):264-95.

7. Cekic D, Cetinkaya A, Avan A, Apak R. Correlation of total antioxidant capacity with reactive oxygen species (ROS) consumption measured by oxidative conversion. J Agric Food Chem. 2013;61:5260-70.

8. Adim EU, Dingwoke EJ, Adamude FA, Edenta C, Nwobodo NN, Offiah RO, et al. Bacteriostatic and bactericidal effects of ethyl acetate root bark extract of terminalia avicennioides on methicillin-resistant Staphylococcus aureus. Afri $J$ Biochem Res. 2018;13:524-34

9. Cowan MM. Plant products as antimicrobial agents. Clin Microbiol Rev. 1999;12:564-82.

10. Tee PL, Yusof S, Mohamed S. Antioxidant properties of roselle (Hibiscus sabdariffa) in linoleic acid model system. Nutri Food Sci. 2002;1:17-20.

11. Padayachee $B$, Baijnath $H$. An overview of the medicinal importance of Moringa. J Med Plants Res. 2012;6(48):5831-9.

12. Anelise SNF, Carla RFV, Matheus S, Claudia ALC, Maria do Carmo C, Zefa VP. Evaluation of antioxidant activity, total flavonoids, tannins and phenolic compounds in psychotria leaf extracts. Antioxidants. 2014;3:745-57.

13. Surai PF. Silymarin as a natural antioxidant: An overview of the current evidence and perspectives. Antioxidants. 2015;4(1):204-47.

14. Farooq F, Rai M., Tiwari A, Khan AA, Farooq S. Medicinal properties of Moringa oleifera: An overview of promising healer. J Med Plants Res. 2012;6(27):436874

15. Martín-Sánchez AM, Cherif S, Ben-Abda J, Barber-Vallés X, Pérez-Álvarez JÁ, Sayas-Barberá E. Phytochemicals in date co-products and their antioxidant activity. Food Chem. 2014;158:513-20.

16. LiY, Zhang JJ, Xu DP, Zhou T, ZhouY, Li S, Li HB. Bioactivities and health benefits of wild fruits. Int J Mol Sci. 2016;17(8). 
17. Akindele PO, Fatunla OA, Ibrahim KA, Afolayan CO. Antibacterial and phytochemical screening of calotropis procera leaf extracts against vancomycin and methicillin resistant bacteria isolated from wound samples in hospital patients. J Comple Altern Med Res. 2017;2:1-14

18. Kouakou-Siransy G, Sahpaz S, Irié-Nguessan G, Datte Y, Kablan J, Gressier B, Bailleul F. Oxygen species scavenger activities and phenolic contents of four West African plants. Food Chem. 2010;118:430-5

19. Alanon, ME, Castro-Vazquez L, Diaz-Maroto MC, Hermosin-Gutierrez I, Gordon $\mathrm{MH}$, Perez-Coello MS. Antioxidant capacity and phenolic composition of different woods used in cooperage. Food Chem. 2011;129:1584-90.

20. Dhakar RC, Maurya SD, Pooniya BK., Bairwa N, Gupta M, Sanwarmal. Moringa: The herbal gold to combat malnutrition. Chro Young Scientists. 2011;2:119-26.

21. Sharma N, Gupta PC, Rao Ch.V. Nutrient content, mineral content and antioxidant activity of Amaranthus viridis and Moringa oleifera leaves. Res J Med Plants. 2012;6(3):253-9.

22. Williams LL. Moringa olefiera: Could this be an Answer to our Need for an Alternative to Fighting Drug-Resistance and Chronic Infections? Med Aromat Plants. 2013;2:e142.

23. Mbikay M. Therapeutic potential of moringa oleifera leaves in chronic hyperglycemia and dyslipidemia: A review. Front Pharmacol. 2012;3:24-34

24. McKay DL, Chen CY, Saltzman E, Blumberg JB. Hibiscus sabdariffa L. tea (tisane) lowers blood pressure in prehypertensive and mildly hypertensive adults. J Nutr. 2010;140(2):298-303.

25. Banu KS, Cathrine L. General techniques involved in phytochemical analysis. Int J Adv Res Chem Sci. 2015;2:25-32.

26. Azmin SNHM, Manan ZA, Alwi SRW, Chua SL, Mustaffa AA, Yunus NA. Herbal processing and extraction technologies. Sep Purif Rev. 2016;45:305-20
27. Santhi K, Sengottuvel R. Qualitative and quantitative phytochemical analysis of Moringa concanensis Nimmo. Int J Curr Microbiol App Sci. 2016;5(1):633-40

28. Torres-Castillo JA, Sinagawa-García SR, Martínez GC, López-Flores AB

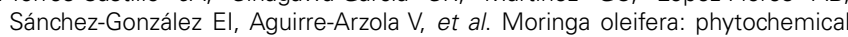
detection, antioxidants, enzymes and antifugal properties. Int J Exp Botany. 2013;82:193-202

29. Meir S, Kanner J, Akiri B, Philosoph-Hadas S. Determination and involvement of aqueous reducing compounds in oxidative defense system of various senescing leaves. J Agric Food Chem. 1995;43:1813-9.

30. Ekaluo UB, Ikpeme EV, Udensi OU, Ekerette EE, Usen SO, Usoroh SF Comparative in vitro assessment of drumstick (moringa oleifera) and neem (azadiracta indica) leaf extracts for antioxidant and free radical scavenging activities. Res J Med Plants. 2015;9:24-33.

31. Anokwuru CP, Esiaba I, Olusola A, Ayobami OA. Polyphenolic content and antioxidant activity of hibiscus sabdariffa calyx. Res J Med Plants. 2011;5:55766.

32. Das SH. In Vitro evaluation of phytochemical, antimicrobial and antioxidan activity of calyces of roselle (Hibiscus Sabdariffa L.) Int J Pharm Sci Res. 2014;5(8):3364-9.

33. Bukar A, Tukur Z. Adulticidal potentials of dichloromethane extracts of some selected plant leaves against culex mosquitoes. Bayero J Pure App Sci. 2017;10(2):38-42.

34. Pakade V, Cukrowska E, Chimuka L. Comparison of antioxidant activity of Moringa oleifera and selected vegetables in South Africa. South Afr J Sci. 2013;9:109-15

35. Aiyegoro OA, Okoh Al. Phytochemical screening and polyphenolic antioxidant activity of aqueous crude leaf extract of Helichrysum pedunculatum. Int J Mol Sci. 2009;10:4990-5001.

\section{GRAPHICAL ABSTRACT}

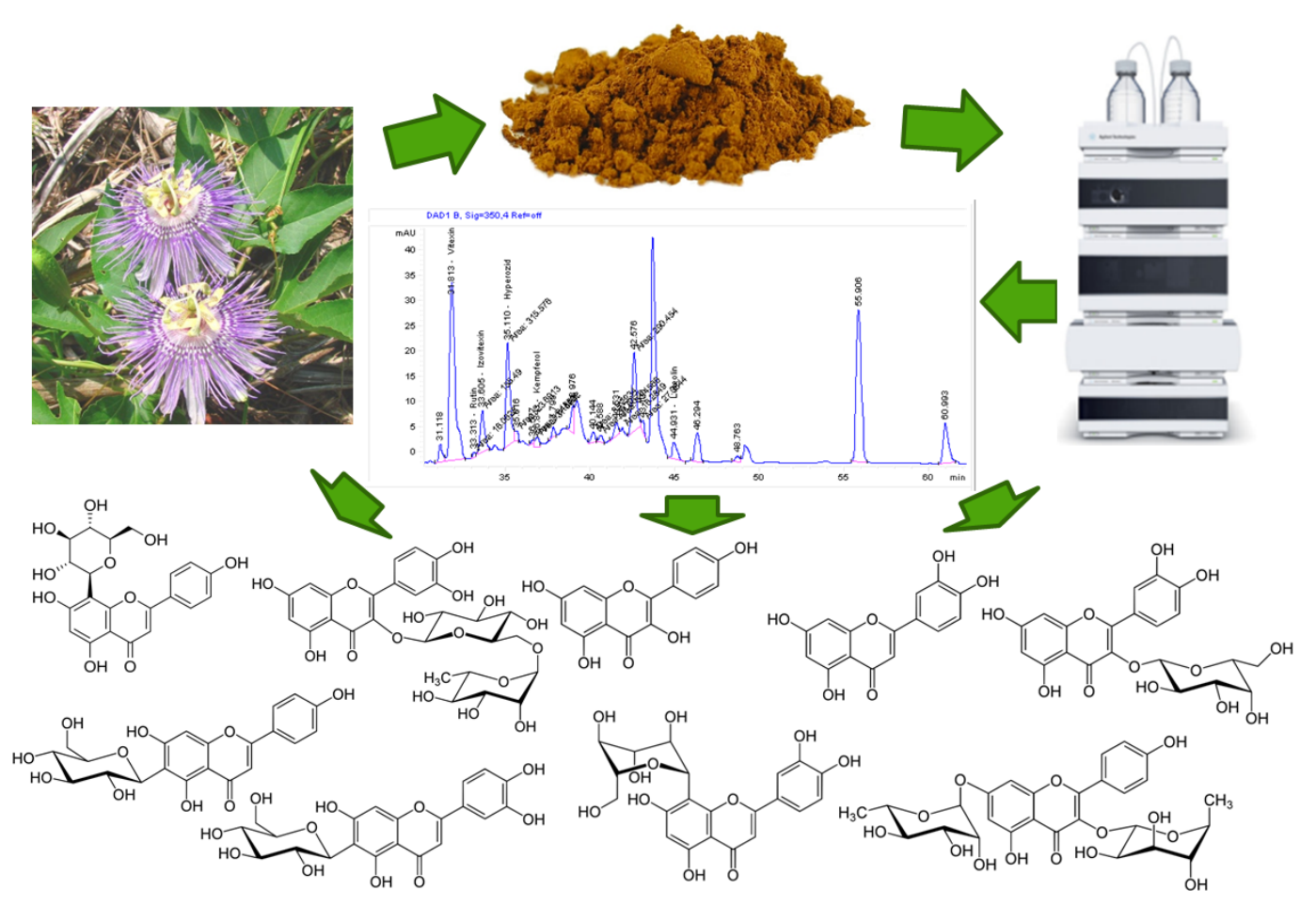

\section{SUMMARY}

Comparative free radical scavenging efficacy of ethylacetate leaves extract of Moringa oleifera and ethylacetate petal extract of Hibiscus sabdariffa was undertaken. Results established that ethylacetate extract of the Petals of Hibiscus sabdariffa has more reducing power and free radical scavenging efficacy compared to ethylacetate extract of Moringa oleifera leaves. These plant parts could serve as novel sources for clinically effective antioxidants.

Cite this article: Garba A, Dingwoke EJ, Adamude FA, Nwobodo NN, Lawan MM. Comparative Free Radical Scavenging Efficacy of Leaves Extract of Moringa Oleifera and Petals Extract of Hibiscus Sabdariffa. Pharmacog J. 2019;11(6):1342-6. 